\title{
Growth Potential of Publicly Traded Brazilian Companies: Accounting and Market Overview
}

\author{
By Ellen Cristina Baradel \\ Fabiano Guasti Lima ${ }^{\dagger}$ \\ Alexandre Assaf Neto
}

The proposal of this paper is to check the relevance of accounting information through factors that affect the growth potential (GP) of the non-financial Brazilian publicly owned companies from 2002 to 2012. The target is to identify which variables that better capture the GP and check the impact of adopting International Financial Reporting Standards (IFRS), confront the accounting vision against market vision. The results signalize that the GP is measured better with market information and that IFRS's quality of information is not enhanced. For the market, size, indebtedness and the return on assets have been relevant to measure the GP while in the accounting vision, size is not relevant.

Keywords: Accounting variables, Growth potential, International standards, Market variables, Value relevance.

\section{Introduction}

Investors have a fundamental role in publicly owned companies on what refers to fundraising. This is because they exchange the available financial resources of today with larger returns in the future. Therefore, knowing the growth potential of the companies is a fundamental way to spread interest of investing in the companies, given the search for better opportunities that may be translated into operations that offer a larger return with a smaller risk.

In order to contribute in the search for better investments, the present paper studies the analysis of a variable "growth potential", understood here as the exploitation of opportunities in the present date that indicate a favorable and growing situation in order to make reaching a position better than the one faced in the present, in terms of return, possible.

The target is to analyze the growth potential of Brazilian publicly owned companies, except for financial companies, under two points of view: an accounting point of view and a market point of view. The proposal is to confront variables generated from accounting against variables generated by the market, in the aspect of growth potential. This is because on one side there is accounting, with information supported by presuppositions and based on past

\footnotetext{
* Accountant, School of Economics, Management and Accounting, University of São Paulo, Brazil.

${ }^{\dagger}$ School of Economics, Management and Accounting, University of São Paulo, Brazil.

${ }^{\ddagger}$ Researcher and Consultant, Assaf Institute, Brazil.
} 
events and on the other side, there is the market, with dynamic information yet loaded with speculation.

The evolution of research in the accounting areas, together with the introduction of the accounting international standards have increased the relevance of accounting to investor's decision making. For investors, accounting information is relevant when financial statements report facts economically known and capable to change the perception of company value and when such statements enable making company projections. On the other hand, macroeconomic dynamism and the inherent characteristics of the Brazilian market make such information decrease the relevance of the accounting data for making a decision.

Therefore, having in mind that the investor aims at finding the best investment opportunities and given the uncertainty of relevance of the accounting information of making a decision in the Brazilian scenario, this paper presents the following research question: Which variables better capture the growth potential of non-financial publicly owned Brazilian companies: market or accounting?

The target is to examine which are the master variables that cause impact in the growth potential of companies and to test which one - accounting information or market information - most trustworthy represents the reality of Brazilian companies on what refers to growth potential.

For that, this paper shall analyze whether the variables: size, indebtedness, return on assets, liquidity, age, industry and the accounting standard have an influence on growth potential under both the accounting and the market point of view. Those indexes have been chosen by considering the results found out in previous studies (Evans 1987, Elston 2002, Beck et al. 2005, Oliveira and Fortunato 2005, Hermelo and Vassolo 2007, Vlachvei and Notta 2008, Mateev and Anastasov 2010, Su and Vo 2010, Gill and Mathur 2011), and necessarily the possibility to obtain, for the same variable, accounting and market proxy.

The aim is to investigate whether accounting plays the role to generate relevant information for share market, as supported by the accounting standards, mainly by the IFRS standard, which has as presupposition for making decisions, the quality of the accounting information. Therefore, analyzing the impact of adopting accounting standards is also the objective of this paper, given the lack of studies about the subject in Brazil, the dispersion reached by the standard and the proposed objective in the structure of the standard.

Therefore, given the dichotomy between accounting and market information, the difference of this paper is to measure growth potential in the Brazilian economic environment under two sources of information: accounting and market. In other words, to confront accounting information against market information in order to verify which is most relevant to the analysis of the growth potential. This search attempts to employ both the accounting and market variables to measure the growth potential of the companies. 


\section{Theoretical Referential}

\section{Company's Growth Theory}

Hart and Prais (1956), pioneers of studies on the growth of companies, have brought, according to Evans (1987), three contributions to the literature: i) evidence of the relation between the age and dynamism of the company (aspect of life cycle of the growth of the company), ii) need for a larger and more understandable sample; and iii) importance to control the bias of sampling selection and heterocedasticity.

Two main schools, according to Mateev and Anastasov (2010), look for identifying factors that explain the growth of companies. The first addressed to approach the influence of variables such as the size and age of the company over its growth, while the second deals with the influence of several variables such as strategy, organization and the characteristics of the company's owners and managers.

From the first school, stands out Gibrat's Theory developed in 1931 under the key presupposition that the growth of company, at any period, is independent of its size, i.e., the relation between size and growing rate is autonomous.

Under the presupposition of Gibrat's Law, Oliveira and Fortunato (2005) explain that such a law may not be empirically supported, as this law only survives when samples include large size companies or companies that have exhaustive economy scale. As a conclusion, the authors present that the growth of service companies always decreases with the size of the company, fact inconsistent with Gibrat's law. Prior researches (Evans 1987, Elston 2002, Oliveira and Fortunato 2005, Vlachvei and Notta 2008, Su and Vo 2010, Gill and Mathur 2011) equally reject Gibrat's law.

Although these studies do not sustain Gibrat's Law, the results emphasize that the size of the company is significant for the analysis of growth potential. For that, Beck et al. (2005), Hermelo and Vassolo (2007) and Su and Vo (2010) only ponder that the size itself is not capable to explain the behavior and growth possibilities of the companies and that there are other more important factors for explaining the growth of the company.

Oliveira and Fortunato (2005) and Mateev and Anastasov (2010), besides the variable size, use the variable age to verify the impact of the size in the growth of the companies. The results diverge on what refers to the relation of such a variable. Mateev and Anastasov (2010) found out that age causes no significant impact, now Elston (2002) and Vlachvei and Notta (2008) presented a positive and significant relation and Oliveira and Fortunato (2005) asseverate that the growth of the companies decreases with size (Table 1). 
Table 1. Sample, Period and Variable Used in Prior Studies

\begin{tabular}{|c|c|c|c|c|}
\hline & \begin{tabular}{|c|} 
Accounting \\
Variables
\end{tabular} & $\begin{array}{c}\text { Market } \\
\text { Variables } \\
\end{array}$ & Period & Sample \\
\hline Evans (1987) & $\mathrm{X}$ & & $\begin{array}{c}1976- \\
1980\end{array}$ & $\begin{array}{l}100 \text { manufacturing } \\
\text { industries }\end{array}$ \\
\hline Elston (2002) & $\mathrm{X}$ & & $\begin{array}{l}1997- \\
2000\end{array}$ & $\begin{array}{l}341 \text { new market firms } \\
\text { in German }\end{array}$ \\
\hline Beck et al. (2005) & $\mathrm{X}$ & & $\begin{array}{l}1995- \\
1999 \\
\end{array}$ & $\begin{array}{l}4000 \text { firms in } 54 \\
\text { countries }\end{array}$ \\
\hline $\begin{array}{l}\text { Oliveira and } \\
\text { Fortunato }(2005)\end{array}$ & $X$ & & $\begin{array}{l}1995- \\
2001\end{array}$ & $\begin{array}{l}419 \text { firms from } \\
\text { Portuguese service } \\
\text { sector }\end{array}$ \\
\hline $\begin{array}{l}\text { Hermelo and } \\
\text { Vassolo (2007) }\end{array}$ & $\mathrm{X}$ & & $\begin{array}{c}1994- \\
1996\end{array}$ & $\begin{array}{l}34 \text { small and medium } \\
\text { sized firms of Tucumán, } \\
\text { Argentina }\end{array}$ \\
\hline $\begin{array}{l}\text { Vlachvei and Notta } \\
\text { (2008) }\end{array}$ & $\mathrm{X}$ & & $\begin{array}{l}1995- \\
2000\end{array}$ & $\begin{array}{l}178 \text { manufacturing and } \\
\text { trading firms in Greek } \\
\text { Stock Market }\end{array}$ \\
\hline $\begin{array}{l}\text { Mateev and } \\
\text { Anastasov (2010) }\end{array}$ & $\mathrm{X}$ & & $\begin{array}{l}2001- \\
2005\end{array}$ & $\begin{array}{l}560 \text { companies from } \\
\text { Bulgaria, Croatia, } \\
\text { Czech R. Poland, } \\
\text { Romania and Serbia }\end{array}$ \\
\hline Su and Vo (2010) & $\mathrm{X}$ & $\mathrm{X}$ & 2008 & $\begin{array}{l}261 \text { listed companies in } \\
\text { Vietnam }\end{array}$ \\
\hline $\begin{array}{l}\text { Gill and Mathur } \\
\text { (2011) }\end{array}$ & & $\mathrm{X}$ & $\begin{array}{l}2008- \\
2010\end{array}$ & $\begin{array}{l}164 \text { Canadian firms } \\
\text { listed on the Toronto } \\
\text { Stock Exchange }\end{array}$ \\
\hline $\begin{array}{l}\text { Senderovitz et al. } \\
\text { (2015) }\end{array}$ & $\mathrm{X}$ & & $\begin{array}{c}2004- \\
2010 \\
\end{array}$ & $\begin{array}{l}964 \text { Danish fast-growth } \\
\text { firms }\end{array}$ \\
\hline
\end{tabular}

Source: Authors' estimations.

Elston (2002), in spite of showing the significance of size and age in the growth potential of a company, shows that restriction in liquidity causes an impact in the growth independently of those variables. In this sense, Beck et al. (2005) indicated that the most impeditive obstacles to growth are associated to financial questions.

Under the point of view of financial structure, Mateev and Anastasov (2010) indicated that, if all companies have equal access to third party resources, the financial structure of the company would be irrelevant to the growth. However, capital suppliers tend to employ the resources in safer companies, making the financial effect an important variable in determining the growth potential of the company.

Studies such as the one developed by Oliveira and Fortunato (2005), Vlachvei and Notta (2008), Mateev and Anastasov (2010) Su and Vo (2010), and Gill and Mathur (2011) levered and liquidity in order to understand the relations between the structure of capital and growth.

According to Elston (2002), the reason for including the variable liquidity is related to the capacity that such a measure has to verify the degree in which 
the growth of the company varies by the restriction of liquidity. Besides that, with a constant restriction in liquidity, it is possible to focus to another relation, allowing, for example, to separate the effect size from growth itself or due to the financial effects (Elston 2002).

Hermelo and Vassolo (2007), Vlachvei and Notta (2008), Su and Vo (2010) and Gill and Mathur (2011) also indicated that liquidity is of extreme relevance for the growth potential analysis. In addition, the contradicting results of abovementioned studies, Oliveira and Fortunato (2005) voiced their opinion that the financial structure has no effect in the growth rate of the companies.

In terms of indebtedness, Oliveira and Fortunato (2005), Vlachvei and Notta (2008) and Su and Vo (2010) showed that the level of debts is not relevant for growth analysis. Mateev and Anastasov (2010) report that the leverage degree is insignificant for analysis when approached by the GMM method, but when it utilizes the panel of fixed effect, the relation established between the variables is positive and significant. Now, Gill and Mathur (2010) signalize the importance of indebtedness.

With regard to profitability, Hermelo and Vassolo (2007) signalize that this is positively significant, revealing that the most profitable company has more capacity to increase accumulated profits and a larger potential to raise funds from external sources, beyond confirming the importance of the financial factors to determine the growth of companies. In consonance with the results presented by Hermelo and Vassolo (2007), findings by Vlachvei and Notta (2008), Mateev and Anastasov (2010), Gill and Mathur (2011) and Senderovitz et al. (2015) also show the significant role of profitability in the analysis of the growth potential of companies. Senderovitz et al. (2015) include that the relationship performance between fast-growth is moderated however, by market strategy; it is stronger for firms pursuing a broad market strategy rather than a niche strategy.

Under an economic and political point of view, Boubakri et al. (2015) explain that political constraints and reforms aimed at improving a country's political institutions impact firm growth. Hence through improved political institutions firms are incentivized to invest and so to stimulate the firm growth. Boubakri and Saffar (2015) add that culture is very important for the growth potential of companies, because it affects the firm's propensity to invest and thus to grow.

\section{Value Relevance}

The pioneers of Value Relevance research were Ball and Brown (1968). They empirically tested that the return of shares of a company responds to a set of information originated from the financial structure. This first study allowed showing to the academy the relevance of accounting information as well as how much they are utile for investors, given their predictive power.

A piece of information is considered relevant when it is capable of making a person move in a different way and face the knowledge of a new fact (Scott 
1997). The attributes to qualify whether such a piece of information is relevant or not is related to the interest of the one that receives such information. In the majority of studies of Value Relevance, as shown by Holthausen and Watts (2001), the main users are the investors. Therefore, information is considered relevant when it is capable of changing an investor's decision when it refers to the purchase or perception of an expected return.

Francis and Schipper (1999) presented four interpretations to consider accounting information relevant: i) if it is associated with anomalous return; ii) if it may predict results, dividends of future cash flow; iii) if it captures information independently of the source; and iv) if the disclosure of the accounting number modifies the investor's expectations.

This study adopts the Value Relevance concept that accounting information is capable of capturing or summarizing information that causes an impact on price of shares. The option to understanding this in detriment to further ones exposed by them is justified by the fact that this interpretation does not establish that accounting statements are the unique or the first source of information.

More recent studies are developed in researching the Value Relevance look for checking the quality of accounting information under different conceptual structures. In the study developed by Meulen et al. (2007), for instance, they look for finding difference of profit attributes for German companies under the point of view of the IFRS and US-GAAP. For the attribute Value Relevance, it was found that the IFRS captures the same information as the US-GAAP model, fact that suggests that differences caused by changing accounting standards are not valued by the investors. To the contrary, Horton and Serafeim (2010), Gjerde et al. (2008) and Iatridis (2010) signalize that the introduction of the IFRS caused an improvement in the quality of accounting information.

\section{Accounting Standardization in Brazil}

In Brazil, the adoption of international accounting standards type that the IFRS was promoted via the publication of Instruction CVM 457/2007 and the approval of Law 11,638/2007, which gave support for applying the IFRS standard for the fiscal year of 2008. Such a law and instruction enforced publicly owned companies to disclose accounting information according to the IFRS standard starting from 2010 (Gonçalves et al. 2012).

However, even before the publication of Law 11,638/2007, the Federal Accounting Council created, by means of the Resolution 1,055/05, the Accounting Practice Committee (CPC). Composed by several academic members, the Committee includes government and private initiative constituents with the objective to prepare and centralize the construction and issuance of the technical procedures, in order to allow the advancing Brazilian standards to be in harmony with international standards.

Such facts allowed its partial adoption, in 2008, and its full adoption in 2010. During its initial stage, from 2008 to 2010, the companies had the liberty 
to choose disclosing or not their information based on international standards. Starting from that date, its adoption happened in full, being mandatory to disclose the accounting information as proposed by the IFRS for all publicly owned companies.

With the advent of unification of the international standards for the whole world, countless studies (Barth et al. 2001, Daske and Gebhardt 2006, Callao et al. 2007, Santos and Calixto 2010, Gonçalves et al. 2012), started examining the IFRS implantation effect on the relevance of the accounting information produced by this model, as well as on the quality of information generated therefrom.

Texts written by Barth et al. (2001) investigate if the companies that have adopted International Accounting Standards proposed by the IASB reflect accounting information of better quality than the ones that use Brazilian standards, not considering in those samples the American companies operating in the country. Daske and Gebhardt (2006) found similar result. Based on three European countries, they have found that the quality of the disclosure of accounting information significantly increased when the IFRS standard was adopted, regardless whether such an adoption was voluntary or enforced.

Oppositely, Callao et al. (2007) found that companies with their shares negotiated in the stock market of Spain had no improvement in the relevance of financial reports due to the adoption of IFRS, when compared with the application of local accounting standards. This was because the difference between accounting values and market values was larger when accounting information was analyzed under the IFRS standard.

In Brazil, Lima (2010) looked for verifying whether the adoption of a part of the international accounting standards increased the relevance of accounting information. For such an objective, he investigated companies that composed the universe of shares of Ibovespa during the period that goes from 1995 to 2009. The results suggest an improvement after the partial adoption of IFRS.

Based on statements disclosed in 2008 by publicly owned companies, the work developed by Santos and Calixto (2010) reveals the impact of the initial adoption of the IFRS. Such results show both a low adoption rate and diversity that refers to the application of international standards and signalizes an expectation of improvement that refers to the transparency and consistency of accounting information, with a reduction in the asymmetry of information with the increase of market efficiency.

Now with full adoption of standards, Gonçalves et al. (2012) find results that signalize an improvement of the relevance of information by adopting the IFRS, given the increase of explanation power of share price by means of net profit per share and the shareholders' equity per share.

\section{Methodology}

Since the decade of 1960, researches have been, each time more, developed under the Positive approach. In this sense, works normally 
developed by means of quantitative techniques, aim in showing the reality and past events to infer and predict future facts.

With that, this work is sketched under such an approach, considering the intention to explain the relation between the growth potential of publicly owned Brazilian companies with the accounting and market information against the accounting structure before and after adopting international standards, via an empiric model.

The information necessary to make the study feasible has been gathered starting from an Economática ${ }^{\circledR}$ platform. For the accounting information, consolidated reports presented at the end of each fiscal year and for the market value were employed and the commercializing values of organizations during the month of December or each year were observed.

The sampling universe, initially constituted by 686 publicly owned companies with shares negotiated at the São Paulo stock exchange - BMF and Bovespa - was first reduced to 615 companies, given the exclusion of the companies dedicated to the finance industry and, later on, to 507 companies, due to lack of data.

The first cut was made due to the fact that they operate in industries with a need for special analysis, which considerably diverges from the other fields of activity. The second cut was made due to understanding that the companies having zeroed data for the whole period may not contribute to the accomplishment of the objectives proposed by this study.

Therefore, the sample was composed by all companies that have their shares negotiated at the São Paulo stock exchange and that showed, along the period of analysis, at least one full year of information necessary for the creation of the variables of the model. Financial companies were excluded from this study.

The total amount of information, a set of data related to a certain company in a specific year, was different for accounting information and market information. This is because not all the companies had data for two analyses.

The period of analysis includes the years from 2002 to 2012. The choice of that period was made in order to make checking the impact caused by the partial adoption possible, in 2008 and by the mandatory adoption, in 2010, by Brazilian companies, of international accounting standards for measuring their growth potential.

\section{Variables}

The choice of variables adopted in the model have, essentially, considered the study made by Gill and Mathur (2011), Su and Vo (2010) and Mateev and Anastasov (2010).

\section{Dependent variable}

Starting from Gill and Mathurs' (2011) definition, growth potential is how much bigger the company shall be in the future, given the capacity to grow and to develop. This study defines the dependent variable as being the possibility of 
a favorable and crescent situation in the future, given the situations and circumstances experienced by the company today and in periods prior to the analysis. In other words, those are the expectations generated by the investors and managers of the company. They expect that the organization shall be in a better condition in the future, when compared with the scenario that the company is in, considering the information that they have now that the expectation is created, based on the analysis of profitability, liquidity, capital structure and accomplished size.

With this, it is possible to correlate that the growth potential of a company is related to how good the company manages its own resources and the third parties' resources and uses with efficiency the opportunities that are "offered". This is because the assertiveness of such actions affords the company larger probabilities of more favorable results in the future, making possible the accomplishment of the desired growth.

There is little consensus in the literature on the way to measure the growth of companies. However, in agreement with the studies developed by Su and Vo (2010) and Gill and Mathur (2011), the dependent variable is represented by the following equation:

$$
\mathrm{PG}=\frac{M V}{T A} \quad \underline{\text { Equation } 1}
$$

where:

GP is the growth potential of the company, MV is the market value of the company, and

TA is the book value of Total Assets.

In this study, the market value of the company is the value that the company is worth facing the investor's analysis, verified through the summation of the PL market value plus the payable accounts. In addition, the accounting value of the Total Assets is the value disclosed in the financial statements for the quantity of the assets and rights that the company has booked during that period.

The choice of this proxy to measure growth potential in the detriment of further options is due to the fact that such metrics capture with precision the value of the company in the future, as shown in prior works ( $\mathrm{Su}$ and Vo 2010, Gill and Mathur 2011). 
Table 2. Proxy of Independent Variables Used in Prior Works

\begin{tabular}{|c|c|c|c|c|c|c|c|c|c|}
\hline & $\begin{array}{l}\text { Evans } \\
(1987)\end{array}$ & $\begin{array}{l}\text { Elston } \\
(2002)\end{array}$ & $\begin{array}{l}\text { Beck et al. } \\
\text { (2005) }\end{array}$ & $\begin{array}{c}\text { Oliveira and } \\
\text { Fortunato (2005) }\end{array}$ & $\begin{array}{c}\text { Hermelo and } \\
\text { Vassolo (2007) }\end{array}$ & $\begin{array}{l}\text { Vlachvei and } \\
\text { Notta (2008) }\end{array}$ & $\begin{array}{c}\text { Mateev and } \\
\text { Anastasov (2010) }\end{array}$ & $\begin{array}{l}\text { Su and Vo } \\
\text { (2010) }\end{array}$ & $\begin{array}{l}\text { Gill and Mathur } \\
\text { (2011) }\end{array}$ \\
\hline Size & NM & NM & $\mathrm{NE}$ & $\mathrm{NE}$ & TS & $\mathrm{NE}$ & $\mathrm{NE}$ and $\mathrm{TA}$ & MVA & TA \\
\hline Age & Years & Years & & Years & & Years & Years & & Years \\
\hline Debts & & & & TL/TA & & TL/TA & TL/TA & TL/TA & TL/TA \\
\hline Liquidity & & & & CA-ST/TA & & $\mathrm{CA} / \mathrm{TA}$ & $\mathrm{CA} / \mathrm{CL}$ & CA/TA & $\mathrm{CA} / \mathrm{CL}$ \\
\hline Profitability & & NR & & & $\mathrm{PBT} / \mathrm{TS}$ & GP/NE & $(\mathrm{PBT}+\mathrm{D}) / \mathrm{TA}$ & $\mathrm{ROE}$ and $\mathrm{CF}$ & $(\mathrm{PBT}+\mathrm{D}) / \mathrm{TA}$ \\
\hline Productivity & & & & & & & $\begin{array}{c}\text { OR/TAN and } \\
\text { OR/NE }\end{array}$ & & OR/TAN \\
\hline Board size & & & & & & $\mathrm{N}^{0}$ director & & & \\
\hline R\&D & & & & & & $\begin{array}{c}\mathrm{R} \& \mathrm{D} / \mathrm{NE} \text { and } \\
\mathrm{R} \& \mathrm{D} / \mathrm{TS}\end{array}$ & & & \\
\hline Technology & & & & & TECHN & & & & \\
\hline $\begin{array}{l}\text { Diversity } \\
\text { Product }\end{array}$ & & & & & MP/TS & & & & \\
\hline Foreign Capital & & & & $\% \mathrm{CH}$ by foreign & & & & & \\
\hline Competitors & & & $\mathrm{N}^{0}$ firms & & & & & & \\
\hline $\begin{array}{l}\text { Financial } \\
\text { Obstacles, Legal } \\
\text { and Corruption }\end{array}$ & & & $\begin{array}{l}\text { rating } \\
\text { from } \\
1 \text { to } 6\end{array}$ & & & & & & \\
\hline
\end{tabular}

Note: CA - Current Assets, CF - Cash Flow, CH - Capital Held by foreign, CL - Current Liabilities, D - Depreciation, GP - Gross Profit, MVA Market Value of Assets, MP - Sale of Main Product, NE - Number of Employees, NM - Not Mention, NR - Net Revenue, PBT - Profit before taxes, R\&D - Research and Development, OR - Operating Revenue, ROE - Return of Equity, ST - Stoke, TA - Total Assets, TAN - Tangible Assets, TECHN - Last Technology, TL - Total Liabilities, TS - Total Sales.

Source: Authors' estimations. 
Independent variables

Prior studies (Evans 1987, Elston 2002, Beck et al. 2005, Oliveira and Fortunato 2005, Hermelo and Vassolo 2007, Vlachvei and Notta 2008, Mateev and Anastasov 2010, Su and Vo 2010, Gill and Mathur 2011) tested several factors that could cause an impact in the growth of companies, as shown in Table 2. With the exception of variable size and performance studied by $\mathrm{Su}$ and Vo (2010), further proxies used in prior works employ accounting information.

Therefore, as this study looks for confronting accounting information against market information by differentiating itself from referenced studies, the choice of independent variables was made starting from the variables shown in Table 2, after the analysis of feasibility to obtain, for the same proxy, both accounting and market information.

Table 3. Description of Independent Variables Included in the Model

\begin{tabular}{|l|c|c|c|}
\hline SIZE & Definitions & $\begin{array}{c}\text { Accounting } \\
\text { Proxy }\end{array}$ & $\begin{array}{c}\text { Market } \\
\text { Proxy }\end{array}$ \\
\hline LEVERAGE & $\begin{array}{c}\text { Size of the } \\
\text { company }\end{array}$ & LN (Total Assets) & $\begin{array}{c}\text { LN (Market Value of } \\
\text { Equity + Indebtedness) }\end{array}$ \\
\hline indebtedness level & Deturn of asset & $\begin{array}{c}\text { Net Profit/Total } \\
\text { Assets } \\
\text { Eebts/(Market Value of } \\
\text { Equity + Indebtedness) }\end{array}$ & $\begin{array}{c}\text { Net Profit/(Market Value } \\
\text { of Equity + } \\
\text { Indebtedness) }\end{array}$ \\
\hline LIQUIDITY & $\begin{array}{c}\text { Level of general } \\
\text { liquidity }\end{array}$ & $\begin{array}{c}\text { Current } \\
\text { Assets/Total Assets }\end{array}$ & $\begin{array}{c}\text { Current Assets/(Market } \\
\text { Value of Equity }+ \\
\text { Indebtedness) }\end{array}$ \\
\hline
\end{tabular}

Source: Authors' estimations.

As it may be noted in Table 3, each variable presented therein has two proxies, one to get accounting information and another to get market information. The choice for the proxies of the variable size was based on the studies of Mateev and Anastasov (2010), Su and Vo (2010) and Gill and Mathur (2011). This is due to the possibility of using comparable information for both visions.

For indebtedness, it the general concept of indebtedness was adopted, according to the works of Oliveira and Fortunato (2005), Vlachvei and Notta (2008), Mateev and Anastasov (2010), Su and Vo (2010) and Gill and Mathur (2011).

The variable ROA, used by Mateev and Anastasov (2010) and Gill and Mathur (2011), was also used in the proposed model by differentiating only what refers to the utilization of net profit instead of profit before taxes and depreciation.

Supported by the works of Vlachvei and Notta (2008) and Su and Vo (2010), the proposed model considered a general liquidity index due to the need for differentiating the proxy to be employed in the accounting vision from the one used in the market vision. 


\section{Control variables}

Control variables age and industry were included with the objective to get the effect of the introduction of international standards in the Brazilian scenario.

Therefore, in order to examine the effect produced in the process of the adoption of the IFRS in Brazil, the period of analysis was divided into: i) prior period (IFRS_PRI); ii) partial period (IFRS_PAR); and iii) mandatory period (IFRS_MAN). For the age three situations were considered: i) surviving companies (SUR); ii) new companies (NEW); iii) extinguished companies (EXT). In order to get species of the industry, a dummy industry was included, following the same separation with Economática ${ }^{\circledR}:$ i) agro and fishing; ii) food and beverage; iii) commerce; iv) civil construction; v) electronics; vi) electric power; vii) industrial machinery; viii) mining; ix) non-metallic minerals; $x$ ) paper and cellulose; xi) oil and gas; xii) chemicals; xiii) steel making and metallurgy; xiv) software and data; xv) telecommunications; $x v i)$ textiles; $x$ vii) transportation and services; xviii) vehicles and parts; and xix) others.

\section{Proposed Model}

In order to meet the proposed objectives of this study, the regression method in the unbalanced panel was adopted with a data in panel that encompasses the period of time that goes from 2002 to 2012 for a set of 507 companies. The use of an unbalanced panel was important to avoid the reduction of the sample and so to keep the generalization of the results to nonfinancial publicly owned Brazilian companies.

Favorable to choosing this method, the literature shows the veracity of tests with the support of prior empirical works (Mateev and Anastasov 2010, Gill and Mathur 2011) that used the same technique to support the hypothesis developed therein.

In order to operationalize the data in the panel, two regression models were developed with the same analysis technique where a model was created starting from the accounting variables, Equation 2, and another based on market variables, Equation 3. Table 4 describes the expected relation for each variable.

$$
\begin{aligned}
G P=\beta_{1}+\beta_{2} & \text { LN SIZ_A }_{\mathrm{i}, \mathrm{t}}+\beta_{3} \text { LEV_A }_{\mathrm{i}, \mathrm{t}}+\beta_{4} \text { ROA_A }_{\mathrm{i}, \mathrm{t}}+\beta_{5} \text { LIQ_A }_{\mathrm{i}, \mathrm{t}}+\beta_{6} \text { IFRS_PRI }_{\mathrm{i}, \mathrm{t}} \\
& +\beta_{7} \text { IFRS_PAR }_{\mathrm{i}, \mathrm{t}}+\beta_{8} \text { IFRS_MAN }_{\mathrm{i}, \mathrm{t}}+\beta_{9} \text { SUR }_{\mathrm{i}, \mathrm{t}}+\beta_{10} \text { NEW }_{\mathrm{i}, \mathrm{t}}+\beta_{11} \text { EXT }_{\mathrm{i}, \mathrm{t}} \\
& +\beta_{12} \text { DUMMY INDUSTRY }_{\mathrm{i}, \mathrm{t}}+\mathrm{e}_{\mathrm{i}, \mathrm{t}}
\end{aligned}
$$

Equation 2 
where:

LN SIZ_A $A_{i, t}$ is the logarithm of the size of the company;

LEV_A $_{i, t}$ is the general indebtedness level;

ROA_A $A_{i, t}$ is the return of asset;

LIQ $A_{i, t}$ is the level of general liquidity;

IFRS_PRI $_{\mathrm{i}, \mathrm{t}}$ IFRS_PAR IF,t $_{\mathrm{i}}$ and IFRS_MAN ${ }_{\mathrm{i}, \mathrm{t}}$ are the dummy variables used in controlling the adoption of international standards; SUR $_{i, t}, \mathrm{NEW}_{\mathrm{i}, \mathrm{t}}$ and EXT $\mathrm{EX}_{\mathrm{i}, \mathrm{t}}$ are the dummy variable used in controlling the age of companies; INDUSTRY $_{\mathrm{i}, \mathrm{t}}$ is the dummy variable used in controlling species of the industries; and $e_{\mathrm{i}, \mathrm{t}}$ is the estimated error of the company $i$ during the period $t$.

$$
\begin{aligned}
G P=\beta_{1}+\beta_{2} & \text { LN SIZ_M }_{\mathrm{i}, \mathrm{t}}+\beta_{3} \text { LEV_M }_{\mathrm{i}, \mathrm{t}}+\beta_{4} \text { ROA_M }_{\mathrm{i}, \mathrm{t}}+\beta_{5} \text { LIQ_M }_{\mathrm{i}, \mathrm{t}}+\beta_{6} \text { IFRS_PRI }_{\mathrm{i}, \mathrm{t}} \\
& +\beta_{7} \text { IFRS_PAR }_{\mathrm{i}, \mathrm{t}}+\beta_{8} \text { IFRS_MAN }_{\mathrm{i}, \mathrm{t}}+\beta_{9} \text { SUR }_{\mathrm{i}, \mathrm{t}}+\beta_{10} \text { NEW }_{\mathrm{i}, \mathrm{t}}+\beta_{11} \text { EXT }_{\mathrm{i}, \mathrm{t}} \\
& +\beta_{12} \text { DUMMYY INDUSTRY }_{\mathrm{i}, \mathrm{t}}+\mathrm{e}_{\mathrm{i}, \mathrm{t}}
\end{aligned}
$$

Equation 3

where:

LN SIZ_M $\mathrm{i}_{\mathrm{i}, \mathrm{t}}$ is the logarithm of the size of the company;

LEV_M ${ }_{i, t}$ is the level of general indebtedness;

ROA_M $\mathrm{i}_{\mathrm{i}, \mathrm{t}}$ is the return of asset;

LIQ_ $\mathrm{M}_{\mathrm{i}, \mathrm{t}}$ is the level of general liquidity;

IFRS_PRI $_{i, t}$, IFRS_PAR ${ }_{i, t}$ and IFRS_MAN ${ }_{i, t}$ are the dummy variables used in controlling adoption of international standards; SUR $_{i, t}, \mathrm{NEW}_{\mathrm{i}, \mathrm{t}}$ and EXT $\mathrm{E}_{\mathrm{i}, \mathrm{t}}$ are the dummy variables used in controlling the age of the companies; INDUSTRY $_{\mathrm{i}, \mathrm{t}}$ is the dummy variable used in controlling species of the industry;

\begin{tabular}{|c|c|c|}
\hline & $\begin{array}{l}\text { Predicted } \\
\text { Sign }\end{array}$ & Theoretical Support \\
\hline SIZE & + & $\begin{array}{c}\text { Beck et al. (2005), Elston (2002), Vlachvei and Notta } \\
\text { (2008) }\end{array}$ \\
\hline LEVERAGE & - & $\begin{array}{c}\text { Oliveira and Fortunato (2005), Su and Vo (2010), } \\
\text { Vlachvei and Notta (2008) }\end{array}$ \\
\hline ROA & + & $\begin{array}{l}\text { Gill and Mathur (2011), Hermelo and Vassolo (2007), } \\
\text { Mateev and Anastasov (2010), Vlachvei and Notta } \\
\text { (2008) }\end{array}$ \\
\hline LIQUIDITY & - & $\begin{array}{c}\text { Mateev and Anastasov (2010), Oliveira and Fortunato } \\
\text { (2005), Vlachvei and Notta (2008) }\end{array}$ \\
\hline IFRS & + & Gonçalves et al. (2012), Santos and Calixto (2010) \\
\hline$\overline{\text { AGE }}$ & + & Elston (2002), Vlachvei and Notta (2008) \\
\hline
\end{tabular}
and $e_{\mathrm{i}, \mathrm{t}}$ is the estimated error of the company $i$ during the period $t$.

Table 4. Expected Relation for Variables Included in the Model

Note: (-) negative relationship with the dependent variable and (+) positive relationship with the dependent variable.

Source: Authors' estimations. 


\section{Results}

\section{Descriptive Statistics}

Accounting model

Table 5 shows the descriptive statistics of both the dependent and independent accounting variables. The information indicates that the GP measured with the accounting information presents a high variability; however, $75 \%$ of the observations correspond to a GP equal or minor than 1.

Table 5. Descriptive Statistics of Accounting Variables

\begin{tabular}{|l|c|c|c|c|c|}
\hline $\begin{array}{l}\text { Accounting } \\
\text { Variables }\end{array}$ & $\begin{array}{c}\text { Number of } \\
\text { observations }\end{array}$ & Minimum & Maximum & Mean & $\begin{array}{c}\text { Standard } \\
\text { deviation }\end{array}$ \\
\hline Potential Growth & 2,740 & 0.01 & 806.44 & 1.38 & 16.10 \\
\hline Size Accounting & 2,740 & 4.37 & 20.33 & 13.98 & 1.96 \\
\hline $\begin{array}{l}\text { Leverage } \\
\text { Accounting }\end{array}$ & 2,740 & 0.01 & 487.22 & 1.87 & 14.56 \\
\hline ROA Accounting & 2,740 & 0.01 & 46.33 & 0.21 & 1.57 \\
\hline $\begin{array}{l}\text { Liquidity } \\
\text { Accounting }\end{array}$ & 2,740 & 0.01 & 1.03 & 0.42 & 0.22 \\
\hline
\end{tabular}

Source: Authors' estimations.

Through the size, you may observe that the majority of the companies contained in the sample are of large size, fact in harmony with the group of companies analyzed therein, large size publicly owned organizations, considering that in Brazil, smaller companies do not count on incentives to open their capital.

By analyzing the behavior of the variable $L e v_{a}$, you may note that $89 \%$ of observations remit to an indebtedness level smaller or equal to 1 and less than $2 \%$ to levels above 100 . Among the companies with a larger indebtedness degree, you may also note the companies with a larger growth potential. This suggests, as signalized by Hermelo and Vassolo (2007), the importance of the financial structure in determining the GP of the companies.

The variable $R O A_{a}$ presents a significant variation. However, $98 \%$ of observations have a ROA equal or smaller than 1 . Here, the variable $L i q_{c}$ presents low vulnerability.

The matrix of correlation has used the Pearson's technique. Starting from data generated out of that, it is possible to perceive that the GP is positively significant with the variables $L e v_{\alpha}$ and $R O A_{\alpha}$. Here, $L i q_{\alpha}$ is negatively significant with variable $S i z_{a}$ and presents an insignificant relation with the control variables of age and IFRS. 
Table 6. Matrix Correlation with Accounting Variables

\begin{tabular}{|c|c|c|c|c|c|c|c|c|c|c|c|}
\hline & PG & $\operatorname{Sin}_{z}$ & $\mathrm{Lev}_{\mathrm{a}}$ & $R O A_{n}$ & $L i q_{=}$ & Sur & New & Ext & IFRS_pri & IFRS_par & IFRS_man \\
\hline PG & 1 & & & & & & & & & & \\
\hline $\operatorname{Sin}_{\mathrm{z}}$ & $-0.1497 * *$ & 1 & & & & & & & & & \\
\hline Leve & $0.3594 * *$ & $-0.2467 * *$ & 1 & & & & & & & & \\
\hline$R O A_{n}$ & $0.1628 * *$ & $-0.2222 * *$ & $0.802 * *$ & 1 & & & & & & & \\
\hline$L i q_{=}$ & $0.0903 * *$ & $-0.1128 * *$ & -0.0273 & $-0.0589 * *$ & 1 & & & & & & \\
\hline Sur & 0.0151 & $-0.0321 *$ & $0.0554 * *$ & $0.0403 * *$ & -0.0145 & 1 & & & & & \\
\hline New & 0.0003 & $0.0984 * *$ & $-0.0491 * *$ & $-0.0418 * *$ & $0.0528 * *$ & $-0.66 * *$ & 1 & & & & \\
\hline Ext & -0.0197 & $-0.0668^{* * *}$ & -0.0175 & -0.0059 & $-0.0395 * *$ & $-0.5626^{* * *}$ & $-0.2498^{* *}$ & 1 & & & \\
\hline IFRS_pri & 0.0172 & $-0.1411 * *$ & -0.0203 & -0.0019 & 0.0169 & $0.0673 * *$ & $-0.3428 * *$ & $0.2904 * *$ & 1 & & \\
\hline IFRS_par & -0.0097 & 0.011 & $0.0412 * *$ & $0.0353^{*}$ & 0.028 & $-0.0344 *$ & $0.1103^{* *}$ & $-0.077 * *$ & $-0.5026^{* *}$ & 1 & \\
\hline IFRS_man & -0.0104 & $0.1449 * *$ & -0.0137 & -0.0287 & $-0.043 * *$ & $-0.0437 * *$ & $0.2792 * *$ & $-0.2509^{* *}$ & $-0.657 * *$ & $-0.3216^{* *}$ & 1 \\
\hline
\end{tabular}

Note: * Level of significance $10 \%$, ** Level of significance $5 \%$.

Source: Authors' estimations. 
A negative relation that is statistically significant was found between the GP and $\mathrm{Siz}_{\alpha}$. This is supported by the findings raised by Evans (1987), Elston (2002), Oliveira and Fortunato (2005) and Gill and Mathur (2011). For Elston (2002), the negative and significant relation applies only to the sample of companies of new economy.

Aligned with the studies of Gill and Mathur (2011), the result of the study herein shall also report the positive and significant relation between $L e v_{\alpha}$ and GP. A positive and significant association has been found between GP and $R O A_{\propto}$, as shown in the literature (Hermelo and Vassolo 2007, Vlachvei and Notta 2008, Mateev and Anastasov 2010, Gill and Mathur 2011). In this sense, Hermelo and Vassolo (2007) assert that companies that are more profitable have more financial resources, to employ in activities that stimulate growth, available.

Although the expected negative relation between GP and $L i q_{a}$, results show the relation positively significant between GP and $L i q_{a}$, as demonstrated in the studies of Su and Vo (2010) and Gill and Mathur (2011).

A positive relation was found between the GP and companies classified as survival and news, while that, for companies qualified as extinguished, such a relation was negative. The association between GP and the phases of IFRS adoption shows that, with an introduction of IFRS, either partial or total, GP is negatively related, while that, for the prior period, the relation was positive. This suggests that, under the accounting point of view, the adoption of IFRS has generated a negative impact on what refers to a growth potential analysis.

\section{Market model}

Table 7 presents the descriptive statistics of the variables based on market information. The market variables that present larger variation are $R O A_{m}$ and $L i q_{m}$. However, distortion caused in these variables refers to a reduced group of companies, being that for $R O A_{m}, 98 \%$ of observations present indication lower than 1 and for liquidity, $87 \%$ of total observation remit to $L i q_{m}$ smaller or equal to 1 .

Table 7. Descriptive Statistic of Market Variables

\begin{tabular}{|l|c|c|c|c|c|}
\hline Market Variables & $\begin{array}{c}\text { Number of } \\
\text { observations }\end{array}$ & Minimum & Maximum & Mean & $\begin{array}{c}\text { Standard } \\
\text { deviation }\end{array}$ \\
\hline Potential Growth & 2,541 & 0.01 & 10.00 & 0.75 & 0.85 \\
\hline Size Market & 2,541 & 7.35 & 20.03 & 14.01 & 2.05 \\
\hline Leverage Market & 2,541 & 0.01 & 1.00 & 0.39 & 0.26 \\
\hline ROA Market & 2,541 & 0.01 & 23.95 & 0.17 & 0.84 \\
\hline Liquidity Market & 2,541 & 0.01 & 22.29 & 0.64 & 1.00 \\
\hline
\end{tabular}

Source: Authors' estimations.

In order to complement the descriptive analysis, Table 8 shows the correlation matrix for variables analyzed under the market model. Therefore, as in the correlation matrix of the accounting model, the technique employed was Pearson's. 
Table 8. Correlation Matrix with Market Variables

\begin{tabular}{|c|c|c|c|c|c|c|c|c|c|c|c|}
\hline & PG & $\operatorname{Sin}_{\mathrm{m}}$ & Lev & $R O A_{2}$ & Liqu & Sur & New & Ext & IFRS_pri & IFRS_par & IFRS_man \\
\hline PG & 1 & & & & & & & & & & \\
\hline $\operatorname{Sin}_{m}$ & $0.3046 * *$ & 1 & & & & & & & & & \\
\hline Leve & $-0.5681 * *$ & $-0.1706^{* *}$ & 1 & & & & & & & & \\
\hline$R O A_{m}$ & $-0.0956 * *$ & $-0.2326 * *$ & $0.0893 * *$ & 1 & & & & & & & \\
\hline$L i q_{m}$ & $-0.2496 * *$ & $-0.3313 * *$ & 0.0231 & $0.4562 * *$ & 1 & & & & & & \\
\hline Sur & $-0.131 * *$ & $-0.063 * *$ & $0.0844 * *$ & $-0.0327 *$ & $0.0821 * *$ & 1 & & & & & \\
\hline New & $0.223 * *$ & $0.1618 * *$ & $-0.1538 *$ & $-0.038 *$ & $-0.1081 * *$ & $-0.647 * *$ & 1 & & & & \\
\hline Ext & $-0.0721 * *$ & $-0.093 * *$ & $0.0574 * *$ & $0.0823 * *$ & 0.0113 & $-0.5782 * *$ & $-0.248 * *$ & 1 & & & \\
\hline IFRS_pri & $-0.0361 *$ & $-0.1676 * *$ & $0.0383 *$ & $0.0374 *$ & $0.0771 * *$ & $0.0731 * *$ & $-0.357 * *$ & $0.2891 * *$ & 1 & & \\
\hline IFRS_par & -0.0295 & 0.0233 & -0.0176 & -0.0167 & -0.0124 & $-0.0391 * *$ & $0.1232 * *$ & $-0.0821 * *$ & $-0.5108 * *$ & 1 & \\
\hline IFRS_man & $0.0659 * *$ & $0.1642 * *$ & -0.0268 & -0.0265 & $-0.074 * *$ & $-0.0461 * *$ & $0.2848 * *$ & $-0.2463 * *$ & $-0.6519 * *$ & $-0.3189 * *$ & 1 \\
\hline
\end{tabular}

\begin{tabular}{l|c|c|c|c|}
\hline IFRS_man & $0.0659 * *$ & $0.1642 * *$ & -0.0268 & -0.0265 \\
\hline
\end{tabular}

Source: Authors' estimations. 
GP is negatively significant with variables $L e v_{m}, R O A_{m}$ and $L i q_{m}$ and positively significant with variable $S i z_{m}$. Besides that, $S i z_{m}$ presents a significant relation with variables of age, this being positive for both new and surviving companies and negative for the extinguished ones. On what refers to the adoption of international standards, this does not present a significant relation just for the period of partial adoption.

The positive and statistically significant association between GP and $S i z_{m}$ suggests that the market understands that larger companies have larger growth potential. A negatively significant relation between GP and $L e v_{m}$ signalizing that, to the market, the more indebted the company, the less its growth potential, was observed. This finding may be correlated with the shareholder's interest in dividend distribution.

The relation between GP and $R O A_{m^{*}}$ is negative and significant. This shows that the more the growth potential, the less the return of that company tends to be. A negatively significant relation was observed between the GP and $L i q_{m}$, situation that may be linked to the fact that the companies that wish to grow allocate more resources in opportunities rather than keep them in cash.

The GP was significantly related to the variable age. This suggests that the market considers the stage of survival of the company for analyzing growth potential important. A positive relation was found out between the GP and the new companies, while a negative relation was observed for both the surviving and extinguished companies.

\section{Accounting model versus market model}

By comparing accounting descriptive data against market descriptive data, it is notorious that the divergence produced with accounting information is reduced with market information, with a minor fluctuation of minimum, maximum, average and deviation. While in the accounting model the variables that present a larger variation are growth potential and indebtedness, in the market model those are returned on assets and liquidity. With regard to size, it is possible to note non-material differences between the two models, fact that suggests similarity in perception of the market and accounting, on what refers to aspect.

By confronting the results obtained from the correlation matrix, it is evident that the difference between the coefficients and the relations found among models, are similar only on what refers to the significance of independent variables.

On what refers to the relation between GP and size, for the model with accounting variables, the correlation observed therein was negative and significant, while for the model with market variables, the correlation found was positive and significant. For the variables indebtedness, return of assets and the level of general liquidity, while in the accounting model the relation of those variables to GP was positive, in the market model those relations were negative.

It is important to emphasize that, in descriptive statistics you do not observe changes in the controlling variables. The variability of such variables 
may be partly explained by such change. This fact thus requires the use of techniques of data in the panel to separate these effects.

\section{Regression in Panel}

\section{Accounting model}

Considering only the accounting information for measuring independent variables, simple regression and panels' regressions were generated under both fixed and random effects. Tests of Chow and Hausman were applied to choose better appropriate method.

Given the results presented by the abovementioned tests, the simple regression and random effect panel were discarded, and the fixed effect panel was kept. It is worth to emphasize that the adoption of the fixed effect panel implies the existence of a fixed value in the intercept for each company belonging to the sampling universe. It also implies the omission of variables that do not modify along the time.

Given that, the main results of the relation between the GP and independent variables are presented in Table 9. The analysis of the adjusted $\mathrm{R}^{2}$ indicates that $30.37 \%$ of the growth potential are explained by the variation of variables $\operatorname{Siz}_{\alpha}, L e v_{\alpha}, R O A_{\alpha}, L i q_{a}$ and IFRS.

On what refers to the significance of the model, you may infer that, based on the value of statistic F, that the model is altogether significant, rejected the null hypothesis that all coefficients of the model are equal to zero and presenting Prob $>F$ equal to zero, fact that shows the relevance of the model employed. Individually, the variables statistically significant are $L e v_{a}, R O A_{a}$, IFRS_PAR and IFRS_MAN.

Table 9. Fixed Effect Panel with Accounting Variables

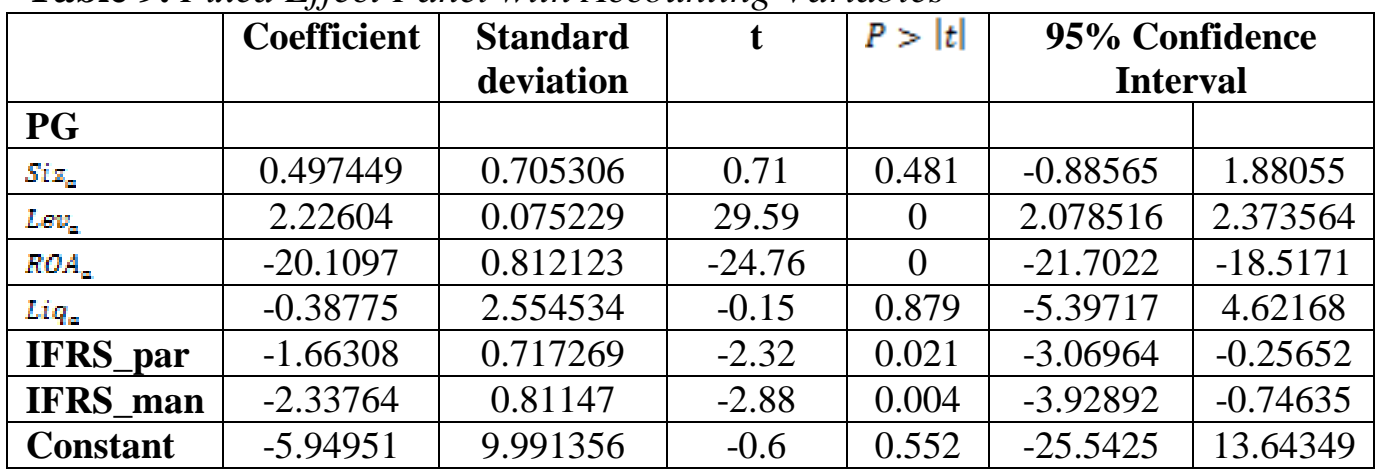

Source: Authors' estimations.

The positive relation between the variables GP and $S i z_{a}$ indicates that the larger the size of the companies, the larger the possibility of growth. This fact may be related to the easiness of getting resources. However, this relation is not statistically significant, fact that corroborates Gilbrat's Theory.

A positive and statistically significant relation was found between GP and $L e v_{\alpha}$. This result supports the argument prior developed that financial credit availability contributes to growth potential. 
Equally, Gill and Mathur (2011) observed the positive and significant relation between the abovementioned variables. The authors justify the result therein found out given that the assessment of corporate tax and payment of interest on debt, in some countries, are tax deductible. In Brazil, such an argument is valid too.

The accounting model still presents a negative and statistically insignificant relation between $L i q_{a}$ and GP, suggesting that publicly owned Brazilian companies, in the accounting vision, prefer using resources in projects that allow growth instead of keeping it in cash.

By means of analysis of adopting IFRS, you may observe that both in the partial period and in the mandatory period those variables were relevant for the model, the GP being smaller in both periods, partial and mandatory, than in the prior period to the application of the IFRS.

With this, in the accounting model, under the point of view of growth potential, you may say that the IFRS impact in GP was negative, i.e., the improvement in the quality of information, as proposed in the framework of the standard, was not met for that end.

With this, Equation 4 presents the accounting model that explains the GP, showing the coefficient, the signal and the value of $p$-valor found for each variable. This last one is identified through the numbers shown between the parentheses, below each variable:

$$
P C=\underset{(0.552)}{-5.949+0.497 S I Z a+2.226 L E V a-20.110 R O A a}-0.388 L I Q a+1.663 \text { IFRSpar }
$$

-0.675 IFRSman $+e$

(0.004)

Equation 4

From the variables included in the accounting model, only $S i z_{\alpha}$ and $L e v_{a}$ turned out to be insignificant, further variables being relevant to the growth potential analysis of the publicly owned Brazilian companies. This shows, according to the bases exposed in the revision of the literature, that GP, in the accounting vision, grows independently of size, what confirms Gilbrat's Theory, and liquidity level presented by the company.

\section{Market model}

Considering only market information for measuring independent variables, equal to the procedure adopted for the accounting model, a simple regression, fixed effect panel regression and random effect panel regression were applied. Chow's test and Hausman's test was also used, to choose the adequate model.

Therefore, for an analysis of the growth potential under the market vision, a panel of fixed effect was also adopted. This presents a fixed value of intercept for each company of the sample and omits variables that do not change along the time, as shown in Table 10. 
Table 10. Fixed Effect Panel with Market Variables

\begin{tabular}{|l|c|c|c|c|c|c|}
\hline & Coefficient & $\begin{array}{c}\text { Standard } \\
\text { deviation }\end{array}$ & $\mathbf{t}$ & $\boldsymbol{P}>|t|$ & \multicolumn{2}{|c|}{ 95\% Conf. Interval } \\
\hline PG & & & & & & \\
\hline Siz $\bar{m}_{m}$ & 0.406697 & 0.018448 & 22.05 & 0 & 0.370519 & 0.442874 \\
\hline Lev $_{m}$ & -1.41572 & 0.05523 & -25.63 & 0 & -1.52403 & -1.30741 \\
\hline ROA $_{m}$ & 0.046251 & 0.014982 & 3.09 & 0.002 & 0.01687 & 0.075632 \\
\hline Liq $_{m}$ & 0.003298 & 0.016487 & 0.2 & 0.841 & -0.02903 & 0.03563 \\
\hline IFRS_par & -0.26258 & 0.023598 & -11.13 & 0 & -0.30885 & -0.2163 \\
\hline IFRS_man & -0.3398 & 0.025365 & -13.4 & 0 & -0.38954 & -0.29005 \\
\hline Constant & -4.51325 & 0.27059 & -16.68 & 0 & -5.04389 & -3.9826 \\
\hline
\end{tabular}

Source: Authors' estimations.

The market model that adjusted $\mathrm{R}^{2}$ indicates that $42.67 \%$ of the growth potential of the companies are explained by the modifications of variables $S i z_{m}, L e v_{m}, R O A_{m}, L i q_{m}$ and IFRS. The value $p$ of statistic $F$ shows the relevance of the model with a high degree of significance and Prob $>F$ equal to zero. Therefore, the model altogether is significant. Individually, the variables $S i z_{m}, L e v_{m}, R O A_{m}$, IFRS_PAR and IFRS_MAN are significant, with $P>|t|$ larger than $1 \%$, while $L i q_{m}$ is not significant.

The market model shows a positive relation and is statistically significant between variables GP and Siz $_{m}$ indicating that in the Brazilian scenario, under the point of view of the market, larger companies tend to have a larger GP. A negative and statistically significant relation was found out between GP and $L e v_{m}$. This finding shows that the market does not positively asses companies that have high indebtedness rates, on what refers to the GP analysis and that the smaller indebtedness level, the larger growth potential of the companies.

Between GP and $R O A_{m}$, a positive and statistically significant relation was found. This suggests that companies with a high return rate become attractive and enjoy credit diversity to accomplish projects that aim at a growth that, by its turn, stimulates and supports the growth potential.

The market model yet presents a positive and statistically insignificant relation between variables Liq $_{m}$ and GP. Possibly, the relation is established because the market does not consider the level of liquidity important, on what refers to the growth potential.

With regard to the adoption of accounting international standards, you may note a negative relation that is statistically significant for both tested periods. This indicates that the IFRS adoption has not caused a positive impact on the quality of market information.

Equation 5 presents the market model emphasizing the coefficients, the signal and the value of the $p$-valor found for each variable, since this last one identified through a number shown between parentheses below each variable: 


$$
\begin{aligned}
& P C=-4.513+0.407 \text { SIZm }-1.416 L E V m+0.046 R O A m+0.003 L I Q m+0.263 \text { IFRSpar } \\
& \text { (0) (0) }
\end{aligned}
$$

-0.077 IFRSman $+e$

(0)

Equation 5

In the market vision, the only variable that is not significant for the model is $L i q_{m}$, further variables being relevant for the analysis of the growth potential of publicly owned Brazilian companies. These results signalize that, that the market point of view, $S i z_{m}, L e v_{m}, R O A_{m}$ and the IFRS are important factors when it comes to analyzing the GP, while $L i q_{m}$ is not relevant for this analysis.

Accounting model versus market model

By confronting the results obtained in the panel regression of the accounting model against the market model, one sees that the size variable gains statistical significance in the market view. This shows that Gibrat's Theory is valid only for the accounting model (Table 11).

Table 11. Comparing Accounting Panel Against Market Panel

\begin{tabular}{|l|c|c|c|c|}
\hline & \multicolumn{2}{|c|}{ Accounting Model } & \multicolumn{2}{c|}{ Market Model } \\
\hline & Coefficient & $P>|t|$ & Coefficient & $P>|t|$ \\
\hline PG & & & & 0 \\
\hline Siz & 0.497449 & 0.481 & 0.406697 & 0 \\
\hline Lev & 2.22604 & 0 & -1.41572 & 0.002 \\
\hline ROA & -20.1097 & 0 & 0.046251 & 0.841 \\
\hline Liq & -0.38775 & 0.879 & 0.003298 & 0 \\
\hline IFRS_par & -1.66308 & 0.021 & -0.26258 & 0 \\
\hline IFRS_man & -2.33764 & 0.004 & -0.3398 & 0 \\
\hline Constant & -5.94951 & 0.552 & -4.51325 & \\
\hline
\end{tabular}

Source: Authors' estimations.

The relation between GP and indebtedness is statistically significant in both accounting and market models, the guideline obtained is different. This result suggests an impasse between the accounting point of view and the market point of view, considering that while accounting views high indebtedness rate in a positive way, given the fiscal incentive existing in the Brazilian tax law, the market views this fact negatively, considering that a high indebtedness degree may render a less attractive company.

Table 12 groups results obtained under those two points of view and the main studies that support the relation found therein. For the indebtedness variable, Mateev and Anastasov (2010) support both findings (negative and positive): this because the negative relation was found out for the GP measured via the total assets and positive when measured via operating income. 
Table 12. Synthesis of Accrued Results

\begin{tabular}{|l|c|c|c|c|}
\hline & Accounting & Main Studies & Market & Main Studies \\
\hline Siz & Insignificant & $\begin{array}{c}\text { Hernelo and Vassolo } \\
(2007) \text {, Vlachvei and } \\
\text { Notta (2008), Su and } \\
\text { Vo (2010) }\end{array}$ & $\begin{array}{c}(+) \\
\text { Significant }\end{array}$ & Elston (2002) \\
\hline Lev & $\begin{array}{c}(+) \\
\text { Significant }\end{array}$ & $\begin{array}{c}\text { Mateev and } \\
\text { Anastasov (2010), } \\
\text { Gill and Mathur } \\
(2011)\end{array}$ & $\begin{array}{c}(-) \\
\text { Significant }\end{array}$ & $\begin{array}{c}\text { Vlachvei and Notta } \\
(2008)\end{array}$ \\
\hline ROA & $\begin{array}{c}\text { Mateev and } \\
\text { Significant }\end{array}$ & $\begin{array}{c}\text { Anastasov (2010) } \\
\text { Significant }\end{array}$ & $\begin{array}{c}\text { Hernelo and Vassolo } \\
\text { (2007), Vlachvei and } \\
\text { Notta (2008), Mateev } \\
\text { and Anastasov (2010), } \\
\text { Gill and Mathur (2011) }\end{array}$ \\
\hline Liq & Insignificant & $\begin{array}{c}\text { Oliveira and } \\
\text { Fortunato (2005), } \\
\text { Vlachvei and Notta } \\
(2008)\end{array}$ & Insignificant & $\begin{array}{c}\text { Oliveira and Fortunato } \\
\text { (2005), Vlachvei and } \\
\text { Notta (2008) }\end{array}$ \\
\hline IFRS & $\begin{array}{c}\text { (-) } \\
\text { Significant }\end{array}$ & \multicolumn{2}{|c|}{$\begin{array}{c}(-) \\
\text { Significant }\end{array}$} & \\
\hline
\end{tabular}

Source: Authors' estimations.

The analysis established between the independent variables and GP shows that, the accounting model, is influenced by $L e v_{\alpha}$ and $R O A_{\alpha}$, while in the market model you verify that $S i z_{m}, L e v_{m}$ and $R O A_{m}$ are variables that influence GP.

On what refers to the IFRS introduction, it is evident that, for both situations, GP is larger in the period when you used Brazilian standards, being that, with IFRS introduction, even during the partial period, that the variable decreased. This shows that, of the new proposed framework does not increase the quality of the accounting information for analyzing the GP.

By analyzing the determining coefficient presented in both models, you verify that $\mathrm{R}^{2}$ generated starting from the accounting information reveals that the independent variables explain in $30.37 \%$ that the GP of the companies, while that for market model, explaining power if $44.58 \%$.

Starting from these results, it is possible to assert that the market model better explains the GP of companies, when compared with the accounting model, given that $\mathrm{R}^{2}$ of the market model was smaller.

\section{Final Considerations}

In order to meet the objectives proposed in this study, this research has analyzed which information, accounting or market, more trustworthily represents the reality of non-financial publicly owned Brazilian companies in measuring the impact of introducing international accounting standards 
in Brazil. Besides that, the influence of the variables size, indebtedness, return on assets, liquidity, age, industry and accounting standard on what refers the analysis of growth potential of Brazilian companies, has been verified.

The results show that the variable growth potential of publicly owned Brazilian companies, with an exception of financial institutions, is better measured with the market information, rather than with the accounting information. That is, the market information better explains the growth potential of the companies when compared with the accounting information model, under the analysis of determining coefficients. This suggests that, under the investor's point of view, market information is more advantageous for decision making on what refers to the growth potential of the companies. This is a fact that may be linked to the dynamism found out in the market information and that may not be observed in the accounting information. The explanation for accounting not supplying information on time may also be correlated to the fact that some accounting entries follow a framework that, in some cases, does not allow the recognition of certain accounting facts.

The way and intensity of how dependent variables are accepted by the accounting diverges from the perception of the market. Such a fact may be correlated to the difference between time that things happen and that are registered by accounting, generating a time difference among perceptions.

From the accounting point of view, the independent variables that influence growth potential are indebtedness and return on assets. Now, in the market model, the variables that cause an impact in growth potential are size, indebtedness and return on assets. In both models, the introduction of accounting standards was relevant for the analysis of growth potential.

The logic fertility of the work used the accounting and marketing information to measure the same variable, with the objective to compare both types of information and to infer on which one is more relevant for making a decision, under the investor's point of view and seen from the side of the growth potential. Besides that, the results allow the contribution with the Value Relevance research line, as well as the aggregate Finances literature therein.

The present study presents a limitation for responding to the research and analysis problem of the data found out in the field: i) exclusion of all important variables for measuring the growth of the companies described in prior studies; ii) exclusion of the financial industry; iii) lack of control of macroeconomic effects, such as crisis; iv) use of accounting information, net profit and current assets to measure variables as a return on market asset and market liquidity, respectively.

As a suggestion for contributing to future researches with the findings of this research and to attenuate limitations presented herein, it is suggested to i) analyze the growth potential of companies over the years to see if the growth potential measured in a last given year was achieved in the subsequent years; ii) measure the growth potential of businesses through the Tobin's Q Ratio; iii) use EBITID for the variable market liquidity, instead of net profit; v) weigh, in the variable indebtedness, the effect of debt; vi) include a variable to control the effect of crisis; vii) in order to pick up the impact of adopting IFRS, weigh its voluntary adoption 
by the companies, so that the variable to be used considers the year each company has effectively adopted international standards.

\section{References}

Ball R, Brown P (1968) An empirical evaluation of accounting income numbers. Journal of Accounting Research 6: 159-178.

Barth ME, Beaver WH, Landsman WR (2001) The relevance of the value relevance literature for financial accounting standard setting: another view. Journal of Accounting and Economics 31: 77-104.

Beck T, Kunt AD, Maksimovic V (2005) Financial and legal constraints to growth: does firm size matter? The Journal of Finance LX: 1.

Boubakri N, El Ghoul S, Saffar W (2015) Firm growth and political institutions. Journal of Multinational Financial Management 3: 104-125.

Boubakri N, Saffar W (2015) Individualism and Firm Growth. Working paper, revise and resubmit of Journal of Corporate Finance.

Callao S, Jarne JI, Laínez JA (2007) Adoption of IFRS in Spain: Effect on the comparability and relevance of financial reporting. Journal of International Accounting, Auditing and Taxation 16 (2): 148-178.

Daske H, Gebhardt G (2006) International financial reporting standards and experts' perceptions of disclosure quality. Journal of Accounting, Finance and Business Studies 42 (3-4): 461-498.

Elston JA (2002) An Examination of the Relationship between Firm Size, Growth and Liquidity in the Never Market. Discussion paper 15/02. Economic Research Centre, Deutsche Bundesbank.

Evans DS (1987) The relationship between firm growth, size and age: estimates for 100 manufacturing industries. The Journal of Industrial Economics 35: 567-581.

Francis J, Schipper K (1999) Have financial statements lost their relevance? Journal of Accounting Research 37: 319-352.

Gill A, Mathur N (2011) Factors that affect potential growth of Canadian firms. Journal of Applied Finance \& Banking 1: 107-123.

Gjerde O, Knivsfla K, Saettem F (2008) The value-relevance of adopting IFRS: Evidence from 145 NGAAP restatements. Journal of International Accounting, Auditing and Taxation 17: 92-112.

Gonçalves JC, Batista BLL, Macedo MA, Marques JAVC (2012) Análise do impacto do processo de convergência as normas internacionais de contabilidade no Brasil: um estudo com base na relevância da informação contábil [Analysis of the impact of the convergence process to the international accounting standards in brazil: a study based on the value relevance of accounting information]. $12^{\circ}$ Congresso USP de Contabilidade e Controladoria. São Paulo. Retrieved from www.congressousp.fipecafi.org. [Accessed: 03 April 2013]

Harmelo FD, Vassolo R (2007) The determinants of firm growth: An empirical examination. Revista Abante 10(1).

Hart PE, Prais SJ (1956) The analysis of business concentration: a statistical approach. Journal of the Royal Statistical Society 119(2): 150-191.

Holthausen RW, Watts RL (2001) The relevance of the value-relevance literature for financial accounting standard setting. Journal of Accounting and Economics 31: 3-75.

Horton J, Serafeim G (2010) Market reaction to and valuation of IFRS reconciliation adjustments: first evidence from the UK. Accountant Studies 15: 725-751. 
Iatridis G (2010) Internacional Financial Reporting Standards and the quality of financial statement information. International Review of Financial Analysis 19: 193-204.

Lima JBN (2010) A relevância da informação contábil e o processo de convergência para as Normas IFRS no Brasil [The value relevance of accounting Information and the Brazilian convergence process toward IFRS]. Tese (Doutorado em Ciências Contábeis) - Faculdade de Economia, Administração e Contabilidade, Universidade de São Paulo, São Paulo.

Mateev M, Anastasoy Y (2010) Determinants of small and medium sized fast growing enterprises in central and eastern Europe: A panel data analysis. Financial Theory and Practice 34(3).

Meulen SV, Gaeremynck A, Willwkens M (2007). Attribute differences between US GAAP and IFRS earnings: An exploratory study. The International Journal of Accounting 42 (2): 123-142.

Oliveira B, Fortunato A (2005) The dynamics of growth of firms: Evidence from the services sector. Empirica 35 (3): 293-312.

Santos ES, Calixto L (2010) Impactos do início da harmonização contábil internacional (Lei n. 11.638/07) nos resultados das empresas abertas [Impacts of the initial international accounting harmonization (law 11.638/07) on public firms' results]. RAE-eletrônica 9 (1): 1.

Scott WR (1997) Financial Accounting Theory. Toronto: Prentice Hall Inc, $50^{\circ}$ ed.

Senderovitz M, Klyver K, Steffens P (2015) Four years on: Are the gazelles still running? A longitudinal study of firm performance after a period of rapid growth. International Small Business Journal 026242614567483.

Su GS, Vo HT (2010) The relationship between corporate strategy, capital structure and firm performance: An empirical study of the listed companies in Vietnam. International Research Journal of Finance and Economics 50: 62-71.

Vlachvei A, Notta O (2008). Firm Growth, Size and Age in Greek Firms. In Proceedings of International Conference on Applied Economics - ICOAE: 915921. 